\title{
Effects of Vegetation Restoration On Soil Carbon Dynamics In Karst And Non-Karst Regions: A Synthesis of Multi-Source Data
}

\section{Xiaocong Zhu}

Southwest University

Mingguo Ma

Southwest University

Ryunosuke Tateno

Kyoto University

\section{Xinhua He}

Southwest University

Weiyu Shi (S85) ( $\square$ shiweiyu@swu.edu.cn )

Southwest University https://orcid.org/0000-0002-9152-228X

\section{Research Article}

Keywords: Ecological Project, Carbon Sequestration, Karst, Soil Carbon, Climate Change, Nutrient Limitation

Posted Date: April 16th, 2021

DOl: https://doi.org/10.21203/rs.3.rs-391609/v1

License: (c) (i) This work is licensed under a Creative Commons Attribution 4.0 International License. Read Full License 
1 Title: Effects of vegetation restoration on soil carbon dynamics in Karst and non-karst regions: A

2 synthesis of multi-source data

3 Authors and Affiliations:

4 Xiao-Cong Zhu ${ }^{1}$, Ming-Guo Ma ${ }^{1}$, Ryunosuke Tateno ${ }^{2}$, Xin-Hua He ${ }^{3}$, Wei-Yu Shi ${ }^{1, *}$

5 1. Chongqing Jinfo Mountain Karst Ecosystem National Observation and Research Station,

6 School of Geographical Sciences, Southwest University, Chongqing 400715, China;

7 2. Filed Science Education and Research Center, Kyoto University, Kyoto 606-8502, Japan;

8 3. College of Natural Resources and Environment, Southwest University, Chongqing 400715,

$9 \quad$ China;

10 Xiao-Cong Zhu: zhuxccong@,foxmail.com;

11 Ming-Guo Ma: mmg@swu.edu.cn;

12 Ryunosuke Tateno: rtateno@kais.kyoto-u.ac.jp;

13 Xin-Hua He: xinhua.he@uwa.edu.au;

14 Wei-Yu Shi: shiweiyu@swu.edu.cn;

*Corresponding Author

16 Wei-Yu Shi

17 Chongqing Jinfo Mountain Karst Ecosystem National Observation and Research Station, School

18 of Geographical Sciences, Southwest University, Chongqing 400715, China

19 Email: shiweiyu@swu.edu.cn

\section{Abstract}

Backgrounds A large-scale ecological restoration project has been initiated since 1990s in 
southwest China, which is one of the largest areas of rocky desertification globally. However, the different influences and potential mechanisms of vegetation restoration on soil carbon $(C)$ sequestration in karst and non-karst regions are still unclear.

Methods Based on field investigation and multi-source data synthesis, the mechanisms of soil C sequestration were investigated to determine the most important variables affecting the rate of soil C change $(R s)$ in southwest China.

Results Our results show significant differences in soil C sequestration between karst and nonkarst regions with faster and longer $\mathrm{C}$ sequestration in karst regions, where $R s$ was approximately $31 \%$ higher than in non-karst soils. And temperatures could be the primary factor inhibiting soil C sequestration without precipitation. The total effect of nitrogen $(\mathrm{N})$ on $R s$ was positive in both karst and non-karst regions.

Conclusions Phosphorus was the dominant factor limiting the use of $\mathrm{N}$ in karst regions and then resulting in limitation of $\mathrm{C}$ sequestration. The results indicated that soil $\mathrm{C}$ storage could be led to intensify uneven increases due to combination of karst environment and climate change in southwest China in future.

\section{Keywords}

Ecological Project; Carbon Sequestration; Karst; Soil Carbon; Climate Change; Nutrient Limitation

\section{Introduction}

China has approximately 3.44 million $\mathrm{km}^{2}$ of karst areas, about $15.6 \%$ of all the 22 million $\mathrm{km}^{2}$ karst areas globally (Jiang et al. 2014). Karst and non-karst landscapes are heterogeneously distributed with karst regions comprise approximately $26 \%\left(5.1 \times 10^{7}\right.$ ha $)$ of the total land area of southwest China. These areas are expected to be exposed to strong levels of degradation stress from 
human activities, primarily intensive agriculture. Karst regions remain extremely fragile areas that are an important target for vegetation restoration efforts (Wang et al. 2004). Ecological restoration projects were launched in southwestern China during the late 20th century, and include the Grain to Green Project, the Karst Rocky Desertification Restoration Project, and the Natural Forest Protection Project (Bennett 2008; Tong et al. 2018). These intensive large-scale human ecological restoration projects have led to important changes in land surface cover, with most of the degraded lands having been restored to shrublands and forests (Yang et al. 2016).

Soils are the largest carbon (C) pool in terrestrial ecosystems, and vegetation restoration generally enhances soil C sequestration in terrestrial ecosystems (Lal 2004a; Xu et al. 2019). Soil C change is critical for mitigating climate change, but the process and consequent changes in soil organic carbon (SOC) remain unclear. However, several uncertainties remain regarding the rate of soil $\mathrm{C}$ accumulation, processes and its influence factors following the restoration of vegetation in karst regions (Curl 2012; Li et al. 2018a; Martin et al. 2013). Firstly, the rate of soil C change in karst regions still remains unknown. Previous studies have reported that the rate of soil C change can range from approximately $-5 \mathrm{Mg} \mathrm{ha}^{-1} \mathrm{yr}^{-1}$ to $5 \mathrm{Mg} \mathrm{ha}^{-1} \mathrm{yr}^{-1}$ following vegetation restoration in temperate regions globally (Deng et al. 2014a; Hu et al. 2016; Li et al. 2012; Yang et al. 2016), and can reach approximately $13 \mathrm{Mg} \mathrm{ha}^{-1} \mathrm{yr}^{-1}$ in tropical and subtropical regions (Machmuller et al. 2015; Post and Kwon 2000). Secondly, it also remains unclear how C changes are related to various environmental factors. Some studies have shown that vegetation, soil properties, and climate all influence plant growth patterns and the distribution of photosynthesis patterns. This effect leads to changes in the ratio of the influx to the outflow of soil C (Berger et al. 2002). Li et al. (2017) suggested that soil $\mathrm{C}$ and nitrogen $(\mathrm{N})$ content increased significantly following vegetation 
restoration in a karst area. Likewise, Chen et al. (2018) concluded that karst areas had a higher SOC accumulation rate than non-karst aresa, and were likely saturated with N. Other studies have observed a mutual feedback relationship between soil $\mathrm{C}$ and other soil properties (Millard et al. 2010). For example, soil chemical properties and soil bulk density (BD) were found to be most important at controlling soil C changes following vegetation restoration (Brahim et al. 2011). Correspondingly, an increase in soil C storage can reduce BD and improve overall soil quality (Korkanç 2014). In terms of soil microorganisms, tree species, and $\mathrm{N}$ deposition, although some recent studies have begun to incorporate both karst and non-karst forests at site and typical catchment (Chen et al. 2016; Li et al. 2018a; Li et al. 2018b). Nevertheless, these studies were limited in local sampling experiment and site-scale data source, the controls from specific variables on the soil $\mathrm{C}$ accumulation at large spatial differentiation and temporal scales remains unknown.

On the other side, previous studies have also used remote sensing to explore surface soil C, as well as to explore the mechanisms controlling C change in southwest China (Chen et al. 2018; Song et al. 2017; Tong et al. 2018). However, the large-scale study based on remote sensing technologies cannot accurately retrieve the physical and chemical properties of soils (Fensholt and Proud 2012), which makes inference regarding soil dynamics from such studies challenging (Knoblauch et al. 2017). Although some studies have focused on the comparison of soil C dynamics in karst and nonkarst regions, these studies have often ignored the interwoven distribution of the two geomorphologies over an entire region (Labrière et al. 2015).

Our study aims to synthesize data from multiple sources, including broad-scale sampling data from field investigation, remote sensing data, data from the primary literature and existing databases to explore the impact of vegetation restoration on soil C sinks in southwest China. We hypothesized 
that soil $\mathrm{C}$ sequestration is lower in karst regions than non-karst regions but the response of soil C to influencing factors are more sensitive in karst regions than non-karst regions. The objectives of the study were to: (1) estimate and compare soil C dynamics in karst and non-karst regions; (2) identify how soil $\mathrm{C}$ accumulation is affected by climate factors and key soil properties following vegetation restoration; and (3) clarify the potential mechanisms of soil C sequestration in both karst and non-karst soils.

\section{Materials and methodology}

1.1 Sampling and laboratory analysis

A comprehensive search of the literature was first carried out using Web of Science and the China Knowledge Resource Integrated Database (CNKI). To filter papers, we used keywords "soil carbon," "southwest," and "China." The following four criteria were used to refine our research: (1) experiments had to be conducted in southwest China (i.e., Sichuan, Chongqing, Yunnan, Guizhou and Guangxi provinces). (2) Field experiments had to have been carried out after 1999. (3) All data used in the papers were derived from soil field experiments. (4) The experiment recorded relevant site information, including vegetation type (i.e., natural secondary forest, artificial forests, shrubland, grassland, and cropland), soil depth, and sampling time. The following information was compiled for each site: SOC, BD, soil $\mathrm{N}$, soil phosphorus $(\mathrm{P})$, soil $\mathrm{pH}$, vegetation type, sampling time, sampling depth, latitude and longitude, sources of data, mean annual temperature (MAT), and mean annual precipitation (MAP).

In order to augment the sample size, an extensive multisite survey was conducted between July and September 2017 by sampling the soil in southwestern China. At each site, a soil pit was excavated to collect samples generally until the $50 \mathrm{~cm}$ depth. The surface leaf litter and moss were 
carefully removed from the ground at each sampling point before sampling soil. Along the profile, undisturbed soil samples were collected using a standard container (ring cutting sampler with 100 $\mathrm{cm}^{3}$ in volume) for bulk density measurements at four layers of depth: $0-5,5-10,10-20$ and $20-50$ $\mathrm{cm}$. We have recorded sampling depth, location and measured the physical and chemical properties of soil in the laboratory. The complete synthesized dataset included 65 published articles (Table S2) and data from 20 sampling sites (Table S3) covering both karst (228 observation points) and nonkarst regions (548 observation points) (Fig. 1). Data relating to the karst vector distribution came from the Karst Scientific Data Center (https://www.karstdata.cn/). Vegetation types selected for this study included natural secondary forest, artificial forests, shrubland, grasslands, and cropland. In order to increase the comparative study and detect more apparent trends in soil C, the soil layer was divided into depths of $0-10,10-20,20-30$, and $0-100 \mathrm{~cm}$. The recovery time was divided into four groups to depict more apparent trends: $1-6,7-12,13-18$, and $\geq 19$ years, and the type of vegetation used for recovery was divided into five different groups: cropland to natural secondary forest $(\mathrm{CN})$, cropland to artificial forest (CA), cropland to shrubland (CS), cropland to grassland (CG), and cropland to cropland (CC).

We used a "space for time" substitution approach, in which all of the data used in the analysis were designed using a paired site method. We made the assumption that the soil conditions between paired sites were similar prior to changes in land use (Don et al. 2011). Soil C before 1999 was obtained from the 1-km scale Harmonized World Soil Database v1.2 (HWSD) (https://www.iiasa.ac.at/), which is a permanently improved version of the database, improves the accuracy of the China Soil Database compared to the previous version (Deng et al. 2018). Post-1999 soil properties were obtained from both the literature and from field experiments. When MAT and 
MAP data were not found in the original data sources, these data were extracted from the "WorldClim-Global Climate Data" (http://www.worldclim.org/).

MAT and MAP were taken from the WorldClim database and averaged over a 50-year period (1950-2000). The annual and monthly climate data obtained from 108 meteorological stations in southwestern China between 1990 to 2017 (China Meteorological Administration (http://data.cma.cn/)). We used the International Geosphere-Biosphere Program (IGBP) to quantify land use in southwest China prior to 1999 (http://westdc.westgis.ac.cn/) (Loveland et al. 2000). The Finer Resolution Observation and Monitoring of Global Land Cover (FROM-GLC) database was used to summarize these values after 1999 (http://data.ess.tsinghua.edu.cn/). Digital elevation models (DEM) were obtained from NOAA's National Centers for Environmental Information (NCEI) (https://www.ngdc.noaa.gov/mgg/), which are available at a spatial resolution of 1-km.

To explore trends in vegetation productivity over the past two decades in the study area, the spatial distribution and annual variation in gross primary productivity (GPP) and net primary productivity (NPP) were assessed. GPP and NPP datasets were refined from MOD17A2 and MOD17A3, respectively (http://files.ntsg.umt.edu/). The MODIS GPP and NPP datasets used in this study were improved by Zhao et al. (2005) to reduce uncertainties from upstream inputs, and are available at a spatial resolution of 1-km over annual intervals from 2000-2015. The GPP and NPP data were used to analyze the temporal and spatial trends in these parameters using the perpixel unary linear regression model.

\subsection{Data analysis}

In cases where SOM was measured but SOC was not, a correcting factor of 0.58 was used to 
convert organic matter into soil C. The relationships between SOM, SOC, and C stock were calculated using the following formulas (Guo and Gifford 2002):

$$
\begin{gathered}
S O C=S O M \times 0.58 \\
C_{S}=\frac{S O C \times B D \times D}{10}
\end{gathered}
$$

where SOC is soil organic $\mathrm{C}$ concentration $\left(\mathrm{g} \mathrm{kg}^{-1}\right)$; $\mathrm{SOM}$ is soil organic matter $\left(\mathrm{g} \mathrm{kg}^{-1}\right)$; Cs is soil organic $\mathrm{C}$ stock $\left(\mathrm{Mg} \mathrm{ha}^{-1}\right)$; $\mathrm{BD}$ is bulk density $\left(\mathrm{g} \mathrm{cm}^{-3}\right)$ and $\mathrm{D}$ is the thickness of the soil $(\mathrm{cm})$.

In cases where soil BD was not measured, two methods were used to estimate these data. The first method was the use of several variables that showed a curvilinear relationship or a similar trend with another variable. The other was interpolation of the missing values using a predictive mean matching method based on the observed data (Hou et al. 2018). Multiple imputations were carried out by pooling the estimates from five separate datasets using the "MICE" package (version 3.5.0) in R 3.4.3 (R Core Team, Vienna, Austria). The final simulated data could also be used to effectively supplement any missing original observation data (Fig. S1-S2).

Soil sampling depths were not always consistent across different studies. Thus, in order to ensure comparability across studies, we adopted the method of Yang et al. (2011), where the original soil C data were converted to SOC stock values observed within the top $100 \mathrm{~cm}$ of soil using the depth functions developed by Jobbágy and Jackson (2000):

$$
\begin{gathered}
Y=1-\beta^{d 0} \\
X_{100}=\frac{1-\beta^{100}}{1-\beta^{d 0}} \times X_{d 0}
\end{gathered}
$$

For observations where only data associated with the $0-100 \mathrm{~cm}$ soil $\mathrm{C}$ stocks were available, the following equation was used:

$$
X_{d 0}=\frac{1-\beta^{d 0}}{1-\beta^{100}} \times X_{100}
$$


where $Y$ describes the cumulative proportion of soil $\mathrm{C}$ stock from the soil surface to depth $d(\mathrm{~cm}) ; \beta$ is the relative rate of decrease in the soil C stock with depth; $X_{100}$ is the soil C stock in the upper $100 \mathrm{~cm} ; d 0$ is the original soil depth available in individual studies; and $X_{d 0}$ is the original soil C stock. The global average depth distributions for $\mathrm{C}$ were used to calculate $\beta$ (i.e., 0.9786) in these equations.

The soil $\mathrm{C}$ sequestration and the rate of soil $\mathrm{C}$ change were calculated using the following equations, respectively:

$$
\begin{gathered}
\Delta C_{S}=C_{L U 2}-C_{L U 1} \\
R s=\frac{\Delta C_{S}}{\Delta A g e}
\end{gathered}
$$

where $\Delta \mathrm{C}_{\mathrm{S}}$ is the soil $\mathrm{C}$ sequestration $\left(\mathrm{Mg} \mathrm{ha}^{-1}\right), \mathrm{C}_{\mathrm{LU} 2}$ represents the soil $\mathrm{C}$ stock at the experimental sites and $\mathrm{C}_{\mathrm{LU} 1}$ is the soil $\mathrm{C}$ stock of the reference sites; $R s$ is the rate of soil $\mathrm{C}$ change $\left(\mathrm{Mg} \mathrm{ha}^{-1} \mathrm{yr}^{-1}\right)$; and $\Delta$ Age represents the time since the change in land-use (yr).

Next, we explored the bivariate relationships between the selected soil properties, climate variables, and elevation using Pearson's correlation coefficient. Data were $\log _{10}$ transformed to meet normality assumptions prior to building the variable correlation matrix (Table 1). A 2-sample t-test was then performed to analyze differences in soil $\mathrm{C}$ content between karst and non-karst regions. One-way ANOVA with Least Significant Difference (LSD) post hoc comparisons were then used to examine the significant differences in soil $\mathrm{C}$ as a function of restoration ages and vegetation type.

The special distribution of the terrain in southwest China usually leads to a corresponding gradient in the climate (Fig. S3). As such, we used structural equation model (SEM) to understand relationships between elevation, climatic factors, and soil properties, in order to determine the most important variables affecting $R s$. SEM is an extension of multiple regression analysis that is used to 
evaluate the dependence of a target variable on several predictor variables. The standardized effects of climate and soil properties on soil C sequestration were calculated in the model. An acceptable fit model is indicated by $1 \leqslant \mathrm{CMIN/DF}$ (chi-square value/degree of freedom) $\leqslant 3$, GFI (goodness fit index), CFI (comparative fit index), NFI (normed fit index), and IFI (incremental fit index) $>0.9$, respectively, where $0.05 \leqslant \mathrm{p} \leqslant 1.00$, and $0 \leqslant$ RMSEA (root mean square error of approximation) $\leqslant 0.08$ (Grace 2006; Hou et al. 2018). To reduce the risk of bias caused by including samples with missing data, listwise deletion was used to create a sub database for use with the SEM. The R packages "lavaan" was used to conduct assumption checking and structural equation modelling.

\section{Results}

3.1 Soil C dynamics under vegetation restoration

A total of $31.6 \times 10^{6}$ ha of land has been restored in the study area. Of this restored land, 13.6 $\times 10^{6}$ ha is composed of karst land and $18 \times 10^{6}$ ha of on-karst land. (Fig. S4). Our results indicate that soil $\mathrm{C}$ accumulation differs markedly between karst and the non-karst regions. SOC and $\mathrm{N}$ contents were $58.4 \%$ and $75.5 \%$ higher in karst areas than non-karst areas. Soil C:N and N:P in karst were higher compared with non-karst regions, and C:P ratio was the opposite. Both $\mathrm{P}$ and elevation were $12.3 \%$ and $36.8 \%$ lower in karst areas than non-karst areas (Table 1). We found that karst has higher rate of soil C change than non-karst region (i.e. the Rs of karst and non-karst were $6.17 \mathrm{Mg}$ ha-1 yr-1 and 4.71 Mg ha-1 yr-1 in 0-100 cm, respectively.), and overall Rs irrespective of vegetation type, with a mean rate of $1.24 \mathrm{Mg}$ ha- $1 \mathrm{yr}-1,0.73 \mathrm{Mg}$ ha- $1 \mathrm{yr}-1,0.68 \mathrm{Mg}$ ha- $1 \mathrm{yr}-1$ and $5.14 \mathrm{Mg}$ ha$1 \mathrm{yr}-1$ in $0-10,10-20,20-30$ and $0-100 \mathrm{~cm}$, respectively (Fig. 2a). The sequestration of soil $\mathrm{C}$ in the karst areas was always higher than in non-karst regions, regardless of which soil layers were 
examined (Fig. 2b). Specifically, the $0-30 \mathrm{~cm}$ of topsoil accounted for more than $50 \%$ of $R s$, and soil $\mathrm{C}$ sequestration in the total soil column $(0-100 \mathrm{~cm})$, and $\mathrm{C}$ accumulation is higher in karst than it is in non-karst topsoil at 0-10, 10-20 and 20-30 cm depths (Fig. 2).

We found important changes in $R s$ associated with restoration age and vegetation type. $R s$ generally increased with restoration age before decreasing, with similar temporal patterns observed across the different soil layers (Fig. 3). However, this was only observed for the period of 13-18 years, and no differences were observed for the other time periods examined. The greatest $R s$ values from karst and non-karst regions occurred at 13-18 years post-recovery time of $(2.09,1.62,1.26$, and 9.18 $\mathrm{Mg} \mathrm{ha}^{-1} \mathrm{yr}^{-1}$ at a depth of 0-10, 10-20, 20-30, and 0-100 cm, respectively) and 7-12 years after vegetation restoration $\left(1.84,1.20,0.99\right.$, and $7.49 \mathrm{Mg} \mathrm{ha}^{-1} \mathrm{yr}^{-1}$ in $0-10,10-20,20-30$ and $0-$ $100 \mathrm{~cm}$, respectively) (Fig. 3). Rs was also significantly different between karst and non- karst regions from the same vegetation restoration strategy. The $R s$ of $\mathrm{CS}, \mathrm{CG}$, and $\mathrm{CC}$ were significantly higher in karst regions, while $\mathrm{CN}$ and $\mathrm{CA}$ were higher in non-karst regions. The highest values for $R s$ in the karst and non-karst regions were observed for the CS $\left(2.72,2.03,1.61\right.$ and $11.70 \mathrm{Mg} \mathrm{ha}^{-1}$ $\mathrm{yr}^{-1}$ at depths of $0-10,10-20,20-30$, and $0-100 \mathrm{~cm}$, respectively) and $\mathrm{CN}(1.82,0.98,0.83$ and 6.52 $\mathrm{Mg} \mathrm{ha}^{-1} \mathrm{yr}^{-1}$ at depths of 0-10, 10-20, 20-30, and 0-100 cm, respectively) (Fig. 4).

\subsection{Drivers of soil C sequestration}

The SEM analysis revealed that $R s$ was mediated by different factors in karst versus non-karst regions. Together, the predictor variables explained $43 \%$ and $37 \%$ of the spatial variation in Rs, respectively (Fig. 5). Specifically, the effect of $\mathrm{N}$ on $R s$ was positive in both karst and non-karst regions, while the effect of MAT on $R s$ was negative only in the non-karst areas. In contrast, the 
effect of MAP on $R s$ was positive only in karst areas. The standardized direct path coefficients from pH, MAP, N, and BD to $R s$ in karst were $-0.05,-0.19,0.68$, and -0.17 , respectively. The standardized direct path coefficients from MAT and $\mathrm{N}$ to $R s$ in the non-karst regions were -0.32 and 0.52 , respectively. Overall, the total effects on the absolute value of $R s$ in the karst region fell in the following order: $\mathrm{N}>\mathrm{MAP}>\mathrm{P}>\mathrm{BD}>\mathrm{DEM}>\mathrm{MAT}>\mathrm{pH}$, and in the non-karst region: other variables were all significant. to 0.30 and 0.52 to 0.50 , respectively, in the non-karst regions (Fig. S6-S8). and precipitation from 108 meteorological stations were gathered and correlated with regional 
however, MAT significantly increase (Fig. S9). We observed no significant variation in vegetation productivity, measured as GPP and NPP, between karst and non-karst regions (Fig. S10-S11).

\section{Discussion}

\subsection{Soil $\mathrm{C}$ sequestration in karst and non-karst regions}

Vegetation restoration is considered an effective way to increase soil $\mathrm{C}$ sequestration and $\mathrm{C}$ sequestration potential by increasing $\mathrm{C}$ derived from the new vegetation (Guo and Gifford 2002; Miles and Kapos 2008). Increases in soil C storage across different soil profiles (i.e., 0-10, 10-20, 20-30, and 0-100 cm in depth) were observed in both the karst and non-karst regions (Fig. 2). Previous research has demonstrated a significant increase in soil $\mathrm{C}$ storage following vegetation restoration (Chang et al. 2011; Li et al. 2012). Our results consistently revealed greater $R s$ and soil $\mathrm{C}$ sequestration rates in karst regions compared to non-karst regions.

At a global scale, the average rate of soil $\mathrm{C}$ storage following vegetation restoration ranges from 0.45 to $1.1 \mathrm{Mg} \mathrm{ha}^{-1} \mathrm{yr}^{-1}$ (Post and Kwon 2000). The accumulation rate of topsoil $\mathrm{C}$ is around $0.35 \mathrm{Mg} \mathrm{ha}^{-1} \mathrm{yr}^{-1}$ under the 'Grain-for-Green' Program in China (Deng et al. 2014a; Zhang et al. 2010). Xiao et al. (2017a) showed that the rate of soil $\mathrm{C}$ sequestration ranged from approximately 0 to $2.00 \mathrm{Mg} \mathrm{ha}^{-1} \mathrm{yr}^{-1}$ in the top layers of the soil (from $0-10$ to $0-45 \mathrm{~cm}$ ) after cropland conversion in southwest China. Likewise, $R s$ varied between 0.68 and $2.65 \mathrm{Mg} \mathrm{ha}^{-1} \mathrm{yr}^{-1}$ in the uppermost soil layer over the entire study region. However, previous studies have also reported soil C accumulation rates of between 0.085 and $0.29 \mathrm{Mg} \mathrm{ha}^{-1} \mathrm{yr}^{-1}$ in the $0-20 \mathrm{~cm}$ topsoil on the Loess Plateau in China (Deng et al. 2014b; Feng et al. 2013). The Rs observed in our result are at the upper end of the range observed from a global scale. This is consistent with a report by Post and Kwon (2000) that indicated increasing rates of soil $\mathrm{C}$ accumulation when moving from cool temperate climates to subtropical 
regions. They also found that soil organic $\mathrm{C}$ in tropical and subtropical zones was higher than that in temperate zones. In our study, $R s$ and $\mathrm{C}$ sequestration in the $0-30 \mathrm{~cm}$ topsoil layer accounted for more than $50 \%$ of that the total $0-100 \mathrm{~cm}$ soil column (Fig. 2). These results provide evidence that the upper soil levels sequester more $\mathrm{C}$ than deeper soils, which is largely in line with previous studies conducted on this topic Jobbágy and Jackson (2000).

Generally, soil $\mathrm{C}$ accumulation shows a regular temporal pattern following vegetation restoration (Paul et al. 2002). However, the temporal patterns of soil C changes are still not clear due to the spatial heterogeneity for landform, vegetation, soil etc. especially at large spatial scale. Research from tropical and subtropical regions has shown rapid recovery of soil $\mathrm{C}$ to native forest levels 20 years after afforestation (Lemma et al. 2006; Macedo et al. 2008; Rhoades et al. 2000). Consistent with previous research, our study also found that the $R s$ showed an initial rise and then a gradual return of soil $\mathrm{C}$ to pre-vegetation values coincident with vegetation restoration (Fig. 3). This indicating that the soil $\mathrm{C}$ stocks are nearly saturated and reach equilibrium after 20 years of regions than in the karst regions during the early recovery period, the difference was not significant.

$303 \quad R s$ was also significantly higher in karst regions than in non-karst regions during the 13-18 year 304 post-recovery period. $R s$ in the karst and non-karst regions were significantly different in CS and CG compared with $\mathrm{CN}$ and CA (Fig. 4). Higher $\mathrm{C}$ sequestration from karst regions is likely a result of the greater plant inputs and/or due to lower losses of $\mathrm{C}$ at high levels of plant diversity, and it is 
in greater soil $\mathrm{C}$ sequestration (Prommer et al. 2020). In addition, cracked land surfaces often form in the limestone-dominated calcium carbonate typically found in karst regions. This results primarily from the dissolution of water, where plant roots are able to penetrate more deeply into the soil through the cracks, which leads to a species-rich plant community and a more complicated above and belowground community structure (Hahm et al. 2014; Liu et al. 2019).

We also noticed a net increase in soil $\mathrm{C}$ storage by $\mathrm{CC}$ over the previous two decades, and the $R s$ of CC was significantly higher in karst regions than that in non-karst regions (Fig. 4). The increase in soil $\mathrm{C}$ is likely due to the application of crop straw in these regions, as well as to different fertilizer regimes used in the area. The phenomenon of increases in soil $\mathrm{C}$ is probably due to the activities of crop straw application and fertilizer recommendation technique by the Agricultural Ministry of China since the 1990s (e.g. no-till and rotation agriculture represents a relatively widely adopted management system) (Huang and Sun 2006). In the past, crop rotation was the typical agricultural farming method used in the region, which resulted in land degradation due to higher soil erosion rates and soil C loss (Li et al. 2018b; Xiao et al. 2017b). According to Perrin et al. (2008), the use of $\mathrm{N}$ fertilizer in karst regions can reduce soil alkalinity via the input of protons during the process of soil nitrification, which leads to the dissolution of carbonates and the release of $\mathrm{C}$ into the soil. Together, we believe that the increase in soil $\mathrm{C}$ observed in croplands is due largely to the decomposition of carbonate rocks.

\subsection{The influence of environmental factors on soil $\mathrm{C}$ sequestration at a regional scale}

Climate change and soil properties can impact the soil $\mathrm{C}$ cycle through changes in landatmosphere coupling (Lal et al. 2011). Our study found that natural conditions and soil properties 
can affect soil $\mathrm{C}$ dynamics, and these effects differed between karst and the non-karst regions. Generally, vegetation productivity is regarded as the dominant factor influencing $R s$, and changes in $R s$ are largely consistent with increases in vegetation productivity (Liu et al. 2016a; Liu et al. 2016b). MAT and MAP are both highly important climate factors controlling vegetation productivity, and both of these variables can be influenced by topography at the regional scale. Rusco et al. (2001) previously found that soil C in Europe is positively correlated with MAP and negatively correlated with MAT. However, the effect that climate patterns have on soil C was not found to be applicable in southwest China in our study. In non-karst regions, MAT had a direct negative effect on $R s$, while MAP had little effect. In contrast, MAT and MAP showed an opposite trend in karst regions (Fig. 5). MAT and MAP likely effect soil C sequestration through their effects on vegetation growth and microbial decomposition (Hou et al. 2018; Luo et al. 2017), and excessively high levels of MAT and MAP stimulate decomposition, thus inhibiting the activity of soil enzymes and reducing $R s$ (Lal 2004b). Our result suggests that temperatures may be the primary factor inhibiting soil $\mathrm{C}$ sequestration in the study area, while precipitation has little to no effect. Trumbore et al. (1996) estimated that if the global temperature increased by $0.5^{\circ} \mathrm{C}$, soil $\mathrm{C}$ stocks would decrease by approximately 6\%. Likewise, Zeng et al. (2019) predicted that an increase in precipitation should offset the negative effects of rising temperatures on carbonate dissolution. In general, increases in vegetation productivity lead to reductions in BD because of the accumulation of organic matter in soils (Perie and Ouimet 2008). Indeed, temperature has shown a steady upward trend over the past two decades in both karst and non-karst regions (Fig. S9), which has led to decrease in BD through enhanced root production and penetration, resulted in create more pore space (Ding et al. 2017). 

productivity (Ellsworth et al. 2017). Although earlier studies have identified significant links between soil $\mathrm{C}$ and $\mathrm{N}$, pathways that connect other soil properties to soil $\mathrm{C}$ have rarely been identified ( $\mathrm{Li}$ et al. 2012). Chen et al. (2012) reported that both $\mathrm{C}$ and $\mathrm{N}$ concentrations were significantly higher in karst regions than in non-karst regions, due largely to differences in parent material. Li et al. (2017) also found that changes in soil C were driven by differences in parent material following agricultural abandonment, in which the amounts of $\mathrm{C}$ and $\mathrm{N}$ in the soil of farmland and grassland on limestone were significantly higher than those observed on dolomite. The results of our study also indicate that N, P, and BD play an important role in soil C sequestration. In our model, the proportion of the total positive effect of $\mathrm{N}$ on $R s$ was relatively higher in both karst and non-karst regions (Fig. 5). The increase of $\mathrm{N}$ reduced the limitation of $\mathrm{N}$ on $\mathrm{C}$ sequestration and causes negative effects on ecosystem function when reach $\mathrm{N}$ saturation (Chen et al. 2016; Li et al. 2012). BD can potentially influence the accumulation of soil $\mathrm{C}$ via changes in the amount of organic matter and through the development of root systems (Ding et al. 2017). to P-limitation in the long-term deposition of N (Alvarez-Clare et al. 2013). According to our synthesis, the $\mathrm{C}: \mathrm{N}$ and $\mathrm{N}: \mathrm{P}$ in karst was higher than in non-karst regions. This implies that soil availability. P may also be a key factor controlling ecosystem processes that depend on $\mathrm{N}$ saturation, 
Chen et al. (2018) found that P limitation was more evident in non-karst forests than in karst forests, because karst regions are more likely saturated with N. Our model suggests that compared to nonkarst regions, $R s$ in karst regions is more often $\mathrm{P}$-limited because of $\mathrm{N}$ saturation (Fig. 5), while nonkarst regions have a relatively lower rate of change in $\mathrm{N}$ than in $R s$. Therefore, $R s$ in non-karst regions may be less negatively affected by P-driven $\mathrm{N}$ enrichment than that of karst regions (Fig. 6).

\section{Conclusion}

This study found a significant difference in the soil $\mathrm{C}$ sequestration between karst and nonkarst regions, with faster and more persistent $\mathrm{C}$ sequestration in karst region. This finding is due primarily to climate gradients and to the amount of $\mathrm{N}$ present within the soil. Both different patterns of soil C dynamics following vegetation restoration in the karst and non-karst support the found that climate gradients are largely controlled by topographic conditions, and that the increase in temperature that has occurred over the past few decades in southwestern China may have led to limit soil $\mathrm{C}$ sequestration in non-karst regions. In addition, $\mathrm{P}$ is the dominant factor limiting the use of $\mathrm{N}$ in karst regions and then resulting in limitation of $\mathrm{C}$ sequestration. At the regional scale, climate factors play an important role in carbonate dissolution in karst environment. And then it is concluded that soil $\mathrm{C}$ storage could be led to intensify uneven increases due to combination of karst environment and climate change in southwest China in future.

\section{Acknowledgements}

We would like to thank Dr. Murphy Stephen at Yale University for his assistance with English language and grammatical editing of the manuscript. This research was funded by National Natural Science Foundation of China (Nos. 41975114 and 41830648).

\section{References}


Alvarez-Clare S, Mack MC, Brooks M (2013) A direct test of nitrogen and phosphorus limitation to net primary productivity in a lowland tropical wet forest. Ecology 94: 1540-1551. https://doi.org/10.1890/12-2128.1

Bennett MT (2008) China's sloping land conversion program: Institutional innovation or business as usual? Ecol Econ 65: 699-711. https://doi.org/10.1016/j.ecolecon.2007.09.017

Berger TW, Neubauer C, Glatzel G (2002) Factors controlling soil carbon and nitrogen stores in pure stands of Norway spruce (Picea abies) and mixed species stands in Austria. Forest Ecol Manag 159: 3-14. https://doi.org/10.1016/S0378-1127(01)00705-8

Brahim N, Blavet D, Gallali T, Bernoux M (2011) Application of structural equation modeling for assessing relationships between organic carbon and soil properties in semiarid Mediterranean region. Int J Environ Sci Te 8: 305-320. https://doi.org/10.1007/BF03326218

Chang R, Fu B, Liu G, Liu S (2011) Soil carbon sequestration potential for “Grain for Green” project in Loess Plateau, China. Environ Manage 48: 1158-1172. https://doi.org/10.1007/s00267-011$9682-8$

Chen H, Gurmesa GA, Zhang W, Zhu X, Zheng M, Mao Q, Zhang T, Mo J (2016) Nitrogen saturation in humid tropical forests after 6 years of nitrogen and phosphorus addition: hypothesis testing. Funct Ecol 30: 305-313. https://doi.org/10.1111/1365-2435.12475

Chen H, Li D, Xiao K, Wang K (2018) Soil microbial processes and resource limitation in karst and non-karst forests. Funct Ecol 32: 1400-1409. https://doi.org/10.1111/1365-2435.13069

Chen H, Zhang W, Wang K, Hou Y (2012) Soil organic carbon and total nitrogen as affected by land use types in karst and non-karst areas of northwest Guangxi, China. J Sci Food Agric 92: 10861093. https://doi.org/10.1002/jsfa.4591 
Curl RL (2012) Carbon shifted but not sequestered. Science 335: 655. https://doi.org/10.1126/science.335.6069.655-a

Deng L, Liu Gb, Shangguan Zp (2014a) Land-use conversion and changing soil carbon stocks in C hina's 'Grain-for-Green'Program: a synthesis. Global Change Biol 20: 3544-3556. https://doi.org/10.1111/gcb.12508

Deng L, Shangguan Z-p, Sweeney S (2014b) “Grain for Green” driven land use change and carbon sequestration on the Loess Plateau, China. Sci Rep 4: 1-8. https://doi.org/10.1038/srep07039

Deng X, Chen X, Ma W, Ren Z, Zhang M, Grieneisen ML, Long W, Ni Z, Zhan Y, Lv X (2018) Baseline map of organic carbon stock in farmland topsoil in East China. Agr Ecosyst Environ 254: 213-223. https://doi.org/10.1016/j.agee.2017.11.022

Ding J, Chen L, Ji C, Hugelius G, Li Y, Liu L, Qin S, Zhang B, Yang G, Li F (2017) Decadal soil carbon accumulation across Tibetan permafrost regions. Nat Geosci 10: 420-424. https://doi.org/10.1038/NGEO2945

Don A, Schumacher J, Freibauer A (2011) Impact of tropical land-use change on soil organic carbon stocks-a meta-analysis. Global Change Biol 17: 1658-1670. https://doi.org/10.1111/j.13652486.2010.02336.x

Ellsworth DS, Anderson IC, Crous KY, Cooke J, Drake JE, Gherlenda AN, Gimeno TE, Macdonald CA, Medlyn BE, Powell JR (2017) Elevated $\mathrm{CO}_{2}$ does not increase eucalypt forest productivity on a low-phosphorus soil. Nat Clim Change 7: 279-282. https://doi.org/10.1038/nclimate3235

Feng X, Fu B, Lu N, Zeng Y, Wu B (2013) How ecological restoration alters ecosystem services: an analysis of carbon sequestration in China's Loess Plateau. Sci Rep 3: 1-5. https://doi.org/10.1038/srep02846 
Fensholt R, Proud SR (2012) Evaluation of earth observation based global long term vegetation trends_-Comparing GIMMS and MODIS global NDVI time series. Remote Sens Environ 119: 131-147. https://doi.org/10.1016/j.rse.2011.12.015

Grace JB (2006) Structural equation modeling and natural systems. Cambridge University Press.

Guo LB, Gifford RM (2002) Soil carbon stocks and land use change: a meta analysis. Global Change Biol 8: 345-360. https://doi.org/10.1046/j.1354-1013.2002.00486.x

Hahm WJ, Riebe CS, Lukens CE, Araki S (2014) Bedrock composition regulates mountain ecosystems and landscape evolution. Proc Natl Acad Sci 111: 3338-3343. https://doi.org/10.1073/pnas.1315667111

Hou E, Chen C, Luo Y, Zhou G, Kuang Y, Zhang Y, Heenan M, Lu X, Wen D (2018) Effects of climate on soil phosphorus cycle and availability in natural terrestrial ecosystems. Global Change Biol 24: 3344-3356. https://doi.org/10.1111/gcb.14093

Hu Z, Li S, Guo Q, Niu S, He N, Li L, Yu G (2016) A synthesis of the effect of grazing exclusion on carbon dynamics in grasslands in China. Global Change Biol 22: 1385-1393. https://doi.org/10.1111/gcb.13133

Huang Y, Sun W (2006) Changes in topsoil organic carbon of croplands in mainland China over the last two decades. Chin Sci Bull 51: 1785-1803. https://doi.org/10.1007/s11434-006-2056-6

Jiang Z, Lian Y, Qin X (2014) Rocky desertification in Southwest China: impacts, causes, and restoration. Earth-Sci Rev 132: 1-12. https://doi.org/10.1016/j.earscirev.2014.01.005

Jobbágy EG, Jackson RB (2000) The vertical distribution of soil organic carbon and its relation to climate and vegetation. Ecol Appl 10: 423-436. https://doi.org/10.2307/2641104

Knoblauch C, Watson C, Berendonk C, Becker R, Wrage-Mönnig N, Wichern F (2017) Relationship 

grasslands under controlled conditions. Sensors 17: 1483. https://doi.org/10.3390/s17071483

Korkanç SY (2014) Effects of afforestation on soil organic carbon and other soil properties. Catena 123: 62-69. https://doi.org/10.1016/j.catena.2014.07.009

Labrière N, Locatelli B, Laumonier Y, Freycon V, Bernoux M (2015) Soil erosion in the humid tropics: A systematic quantitative review. Agric Ecosyst Environ 203: 127-139. https://doi.org/10.1016/j.agee.2015.01.027

Lal R (2004a) Offsetting China's $\mathrm{CO}_{2}$ emissions by soil carbon sequestration. Climatic Change 65: 263-275. https://doi.org/10.1023/B:CLIM.0000038203.81854.7c

Lal R (2004b) Soil carbon sequestration impacts on global climate change and food security. Science 304: 1623-1627. https://doi.org/10.1126/science.1097396

Lal R, Delgado J, Groffman P, Millar N, Dell C, Rotz A (2011) Management to mitigate and adapt to climate change. J Soil Water Conserv 66: 276-285. https://doi.org/10.2489/jSWC.66.4.276

Lemma B, Kleja DB, Nilsson I, Olsson M (2006) Soil carbon sequestration under different exotic tree species in the southwestern highlands of Ethiopia. Geoderma 136: 886-898. https://doi.org/10.1016/j.geoderma.2006.06.008

Li D, Chen H, Xiao K, Zhang W, Wang K (2018a) Nitrogen biogeochemical cycling and its effects on carbon sequestration in karst ecosystems, southwest China. Research of Agricultural Modernization 39: 916-921.

Li D, Liu J, Chen H, Zheng L, Wang K (2018b) Soil microbial community responses to forage grass cultivation in degraded karst soils, Southwest China. Land Degrad Dev 29: 4262-4270. https://doi.org/10.1002/ldr.3188 
Li D, Niu S, Luo Y (2012) Global patterns of the dynamics of soil carbon and nitrogen stocks following afforestation: a meta-analysis. New Phytol 195: 172-181. https://doi.org/10.1111/j.1469-8137.2012.04150.x

Li D, Wen L, Yang L, Luo P, Xiao K, Chen H, Zhang W, He X, Chen H, Wang K (2017) Dynamics of soil organic carbon and nitrogen following agricultural abandonment in a karst region. J Geophys Rese-Biogeos 122: 230-242. https://doi.org/10.1002/2016JG003683

Liu H, Jiang Z, Dai J, Wu X, Peng J, Wang H, Meersmans J, Green SM, Quine TA (2019) Rock crevices determine woody and herbaceous plant cover in the karst critical zone. Sci ChinaEarth Sci 62: 1756-1763. https://doi.org/10.1007/s11430-018-9328-3

Liu LB, Yang HM, Xu Y, Guo YM, Ni J (2016a) Forest biomass and net primary productivity in southwestern China: A meta-analysis focusing on environmental driving factors. Forests 7: 173. https://doi.org/10.3390/f7080173

Liu M, Xu X, Wang D, Sun AY, Wang K (2016b) Karst catchments exhibited higher degradation stress from climate change than the non-karst catchments in southwest China: An $\begin{array}{llll}\text { ecohydrological } & \text { perspective. } & \text { J } & \text { Hydrol }\end{array}$ https://doi.org/10.1016/j.jhydrol.2016.01.033

Luo Z, Feng W, Luo Y, Baldock J, Wang E (2017) Soil organic carbon dynamics jointly controlled by climate, carbon inputs, soil properties and soil carbon fractions. Global Change Biol 23: 4430-4439. https://doi.org/10.1111/gcb.13767

Macedo M, Resende A, Garcia P, Boddey R, Jantalia C, Urquiaga S, Campello E, Franco A (2008) Changes in soil $\mathrm{C}$ and $\mathrm{N}$ stocks and nutrient dynamics 13 years after recovery of degraded land using leguminous nitrogen-fixing trees. Forest Ecol Manag 255: 1516-1524. 
Machmuller MB, Kramer MG, Cyle TK, Hill N, Hancock D, Thompson A (2015) Emerging land use practices rapidly increase soil organic matter. Nat Commun 6: 1-5. https://doi.org/10.1038/ncomms7995

Martin JB, Brown A, Ezell J (2013) Do carbonate karst terrains affect the global carbon cycle? Acta Carsologica 42.

Miles L, Kapos V (2008) Reducing greenhouse gas emissions from deforestation and forest degradation: global land-use implications. Science 320: 1454-1455. https://doi.org/10.1126/science. 1155358

Millard P, Midwood AJ, Hunt JE, Barbour MM, Whitehead D (2010) Quantifying the contribution 
Prommer J, Walker TW, Wanek W, Braun J, Zezula D, Hu Y, Hofhansl F, Richter A (2020) Increased microbial growth, biomass, and turnover drive soil organic carbon accumulation at higher plant diversity. Global Change Biol 26: 669-681. https://doi.org/10.1111/gcb.14777

Rhoades CC, Eckert GE, Coleman DC (2000) Soil carbon differences among forest, agriculture, and secondary vegetation in lower montane Ecuador. Ecol Appl 10: 497-505. https://doi.org/10.2307/2641109

Rusco E, Jones RJ, Bidoglio G (2001) Organic matter in the soils of Europe: Present status and future trends. Institute for Environment and Sustainability, Joint Research Centre.

Song X, Gao Y, Wen X, Guo D, Yu G, He N, Zhang J (2017) Carbon sequestration potential and its eco-service function in the karst area, China. J Geogr Sci 27: 967-980. https://doi.org/10.1007/s11442-017-1415-3

Tong X, Brandt M, Yue Y, Horion S, Wang K, De Keersmaecker W, Tian F, Schurgers G, Xiao X, Luo Y (2018) Increased vegetation growth and carbon stock in China karst via ecological engineering. Nat Sustainability 1: 44-50. https://doi.org/10.1038/s41893-017-0004-X

Trumbore SE, Chadwick OA, Amundson R (1996) Rapid exchange between soil carbon and atmospheric carbon dioxide driven by temperature change. Science 272: 393-396. https://doi.org/10.1126/science.272.5260.393

Wang SJ, Liu QM, Zhang DF (2004) Karst rocky desertification in southwestern China: geomorphology, landuse, impact and rehabilitation. Land Degrad Dev 15: 115-121. https://doi.org/10.1002/ldr.592

Xiao K, He T, Chen H, Peng W, Song T, Wang K, Li D (2017a) Impacts of vegetation restoration strategies on soil organic carbon and nitrogen dynamics in a karst area, southwest China. Ecol 
551

Xiao S, Zhang W, Ye Y, Zhao J, Wang K (2017b) Soil aggregate mediates the impacts of land uses on organic carbon, total nitrogen, and microbial activity in a Karst ecosystem. Sci Rep 7: 1-10. https://doi.org/10.1038/srep41402

Xu L, Yu G, He N (2019) Increased soil organic carbon storage in Chinese terrestrial ecosystems from the 1980s to the 2010s. J Geogr Sci 29: 49-66. https://doi.org/10.1007/s11442-019-15834

Yang L, Luo P, Wen L, Li D (2016) Soil organic carbon accumulation during post-agricultural succession in a karst area, southwest China. Sci Rep 6: 1-8. https://doi.org/10.1038/srep37118

Yang Y, Luo Y, Finzi AC (2011) Carbon and nitrogen dynamics during forest stand development: a global synthesis. New Phytol 190: 977-989. https://doi.org/10.1111/j.1469-8137.2011.03645.x

Zeng S, Liu Z, Kaufmann G (2019) Sensitivity of the global carbonate weathering carbon-sink flux to climate and land-use changes. Nat Commun 10: 1-10. https://doi.org/10.1038/s41467-019$13772-4$

Zhang K, Dang H, Tan S, Cheng X, Zhang Q (2010) Change in soil organic carbon following the 'Grain-for-Green'programme in China. Land Degrad Dev 21: 13-23. https://doi.org/10.1002/ldr.954

Zhao M, Heinsch FA, Nemani RR, Running SW (2005) Improvements of the MODIS terrestrial gross and net primary production global data set. Remote Sens Environ 95: 164-176. https://doi.org/10.1016/j.rse.2004.12.011 


\section{Supplementary Information:}

573 Additional supporting information may be found appendix in the Supporting Information section.

574

575 Data Accessibility Statement: All data generated or analysed during this study are included in this

576 published article and its supplementary information files. 
Table 1 Information concerning the different soil properties at karst and non- karst sites in southwest China.

\begin{tabular}{|c|c|c|c|c|c|c|c|c|c|c|}
\hline \multirow{2}{*}{$\begin{array}{l}\text { Landform } \\
\text { Variables } \\
\end{array}$} & \multicolumn{5}{|c|}{ Karst } & \multicolumn{5}{|c|}{ Non - karst } \\
\hline & $\mathrm{n}$ & Mean & Range & SD & Skewness & $\mathrm{n}$ & Mean & Range & SD & Skewness \\
\hline $\operatorname{SOC}\left(\mathrm{g} \mathrm{kg}^{-1}\right)$ & 228 & 29.15 & $2.67-117.74$ & 23.53 & 1.31 & 548 & 18.40 & $1.89-116.59$ & 14.22 & 2.52 \\
\hline $\mathrm{N}\left(\mathrm{g} \mathrm{kg}^{-1}\right)$ & 176 & 2.65 & $0.16-13.80$ & 2.30 & 2.03 & 389 & 1.51 & $0.10-8.80$ & 1.03 & 2.04 \\
\hline$P\left(\mathrm{~g} \mathrm{~kg}^{-1}\right)$ & 79 & 0.93 & $0.15-4.05$ & 0.65 & 2.03 & 108 & 1.06 & $0.14-5.49$ & 1.28 & 2.62 \\
\hline $\mathrm{C}: \mathrm{N}$ & 78 & 13.33 & $5.90-39.29$ & 6.11 & 2.38 & 100 & 12.01 & $4.81-34.60$ & 5.01 & 2.50 \\
\hline $\mathrm{C}: \mathrm{P}$ & 78 & 43.20 & $6.85-268.69$ & 48.51 & 3.41 & 100 & 43.93 & $2.46-264.98$ & 41.95 & 2.33 \\
\hline $\mathrm{N}: \mathrm{P}$ & 78 & 3.59 & $0.56-24.61$ & 4.22 & 3.51 & 100 & 3.46 & $0.08-11.40$ & 2.38 & 1.29 \\
\hline $\mathrm{pH}\left(\mathrm{H}_{2} \mathrm{O}\right)$ & 147 & 6.69 & $4.12-9.50$ & 1.20 & -0.28 & 376 & 6.15 & $3.40-9.60$ & 1.54 & 0.36 \\
\hline $\mathrm{BD}\left(\mathrm{g} \mathrm{cm}^{-3}\right)$ & 114 & 1.27 & $0.45-1.94$ & 0.29 & 0.44 & 461 & 1.30 & $0.75-2.00$ & 0.23 & 0.42 \\
\hline $\operatorname{DEM}(\mathrm{m})$ & 228 & 793.32 & $109-3333$ & 476.07 & 1.12 & 548 & 1254.80 & $67-3871$ & 780.17 & 1.08 \\
\hline $\operatorname{MAT}\left({ }^{\circ} \mathrm{C}\right)$ & 228 & 17.38 & $2.13-22.55$ & 2.62 & -0.74 & 548 & 17.23 & $0.48-23.19$ & 4.69 & -1.75 \\
\hline MAP (mm) & 228 & 1325.23 & $752.1-1778.58$ & 207.01 & -0.18 & 548 & 1271.45 & $686.1-1832.32$ & 310.77 & -0.27 \\
\hline
\end{tabular}




\section{Figure captions:}

Fig. 1 Spatial distribution of the observation sites in the dataset. All sites include multiple data entries.

Fig. 2 Changes in soil C stocks at different soil depths after vegetation restoration in karst and nonkarst regions. (a) Rate and proportion of soil C change in the top $100 \mathrm{~cm}$ of the soil column. (b) Soil $\mathrm{C}$ sequestration and proportion in the top $100 \mathrm{~cm}$ of the soil column. Error bars represent $95 \%$ confidence intervals $(\mathrm{CI})$.

Fig. 3 Variation in the rate of soil $\mathrm{C}$ change over time within different soil layers after vegetation restoration for: (a) soil at 0-10 cm, (b) soil at 10-20 cm, (c) soil at 20-30 cm, and (d) soil at 0-100 $\mathrm{cm}$. The symbols $* * *$, and $* * *$ denote values where there are significant differences between the karst and non-karst regions, at $\mathrm{p}<0.05, \mathrm{p}<0.01$, and $\mathrm{p}<0.001$, respectively. Different uppercase letters denote a significant difference among the different restoration stages of the karst at $\mathrm{p}<0.05$. Different lowercase letters denote a significant difference between the different restoration stages in the non-karst regions at $\mathrm{p}<0.05$. Values above the bars represent the number of observations. The error bars illustrate the standard errors (SE).

Fig. 4 Variation in the rate of soil $\mathrm{C}$ change within different vegetation types at different depths after vegetation restoration for: (a) soil at 0-10 cm, (b) soil at 10-20 cm, (c) soil at 20-30 cm, and (d) soil at $0-100 \mathrm{~cm}$. The symbols $*, * *$, and $* * *$ denote values where significant differences occur between the karst and non-karst regions, at $\mathrm{p}<0.05, \mathrm{p}<0.01$, and $\mathrm{p}<0.001$, respectively. Different uppercase letters denote significant differences among the different restoration stages of karst at $\mathrm{p}$ $<0.05$. Different lowercase letters denote significant differences between the different restoration stages of non-karst at $p<0.05$. Values above the bars represent the number of observations. The 
error bars illustrate the standard errors (SE).

Fig. 5 Final structural equation model for rate of soil $\mathrm{C}$ change at depths from $0-100 \mathrm{~cm}$. Green and red colors indicate positive and negative estimates, respectively. Green and red dashed lines indicate insignificant path coefficients $(\mathrm{p}>0.05)$. Numbers on arrows are standardized path coefficients. The $r^{2}$ values represents the proportion of variance in each endogenous variable. The width of the arrow indicates the strength of a path. (a) Model of karst $(n=76)$ with the factors affecting the rates of soil $\mathrm{C}$ change $(\mathrm{CMIN} / \mathrm{DF}=0.754, \mathrm{GFI}=0.987, \mathrm{CFI}=1.000, \mathrm{NFI}=0.957, \mathrm{IFI}=1.015, \mathrm{p}=0.731$, and RMSEA $<0.001)$. (b) Model of non-karst $(n=100)$ with the factors affecting the rates of soil $\mathrm{C}$ change $(\mathrm{CMIN} / \mathrm{DF}=1.792, \mathrm{GFI}=0.972, \mathrm{CFI}=0.978, \mathrm{NFI}=0.953, \mathrm{IFI}=0.979, \mathrm{p}=0.074$, and RMSEA $=0.089)$. The color histogram from left to right is indirect effect, direct effect and total effect.

Fig. 6 A conceptual diagram showing the differences mechanism in soil $\mathrm{C}$ sequestration processes between karst and non-karst areas. The diagram showing different lithology in karst and non-karst areas leading to different distribution of underground soil layers and aboveground vegetation community composition. BD has a negative effect on soil carbon pool growth throughout the study area. MAP and $\mathrm{P}$ in karst areas offset negative impacts on soil carbon pool growth due to $\mathrm{N}$ saturation. Growth of soil $\mathrm{C}$ pools in non-karst areas limited by temperature rise and $\mathrm{N}$ increase. MAT: mean annual temperature; MAP: mean annual precipitation; BD: soil bulk density; N: soil nitrogen; P: soil phosphorus. The upward, downward, and horizontal arrows near the ellipse represent increase, decrease, and no change of the corresponding variables, respectively. The plus and minus signs next to the arrows between the variables indicate the positive and negative effects, respectively 
$626 \quad$ Fig. 1

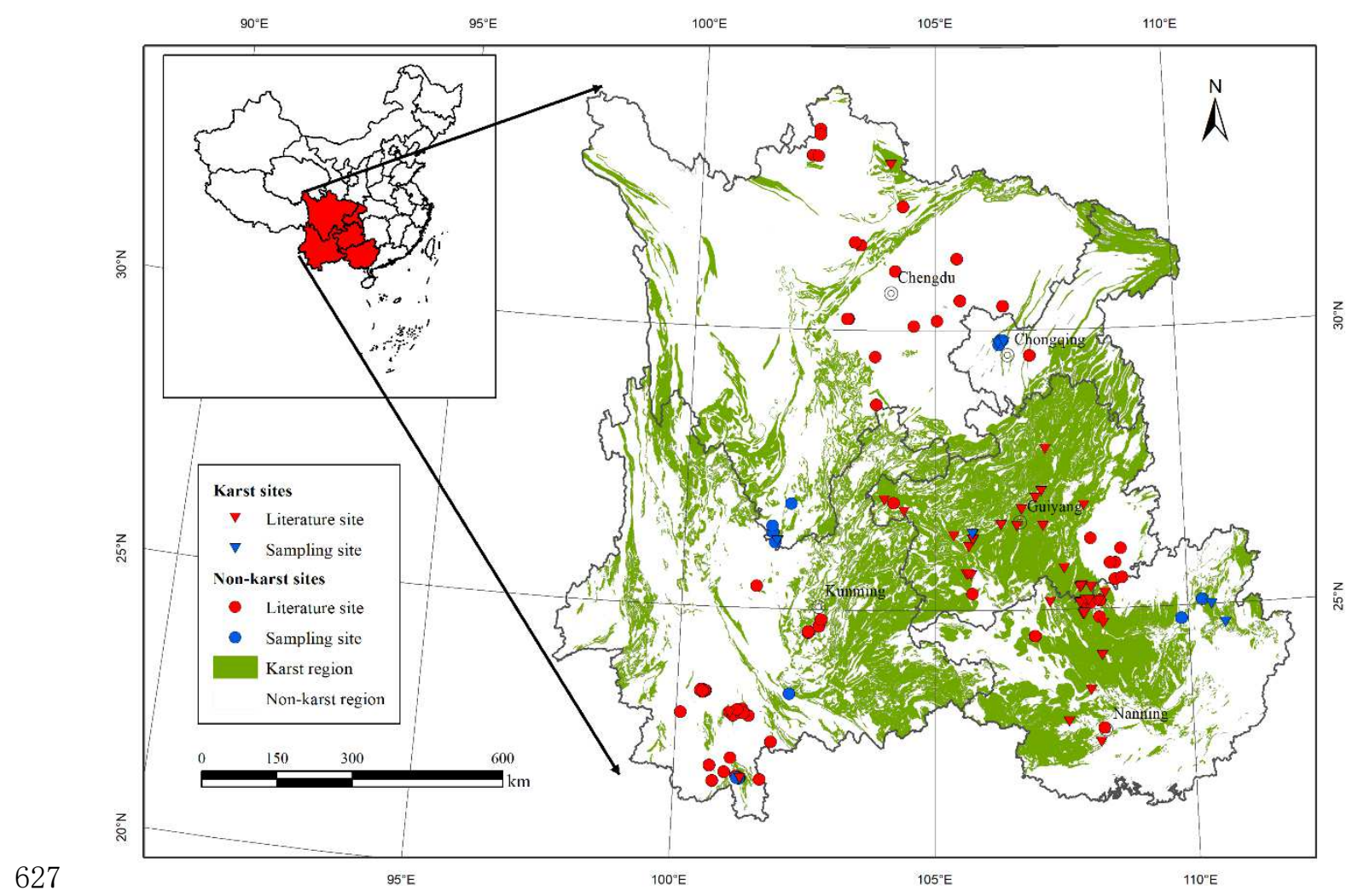

628

629 
631

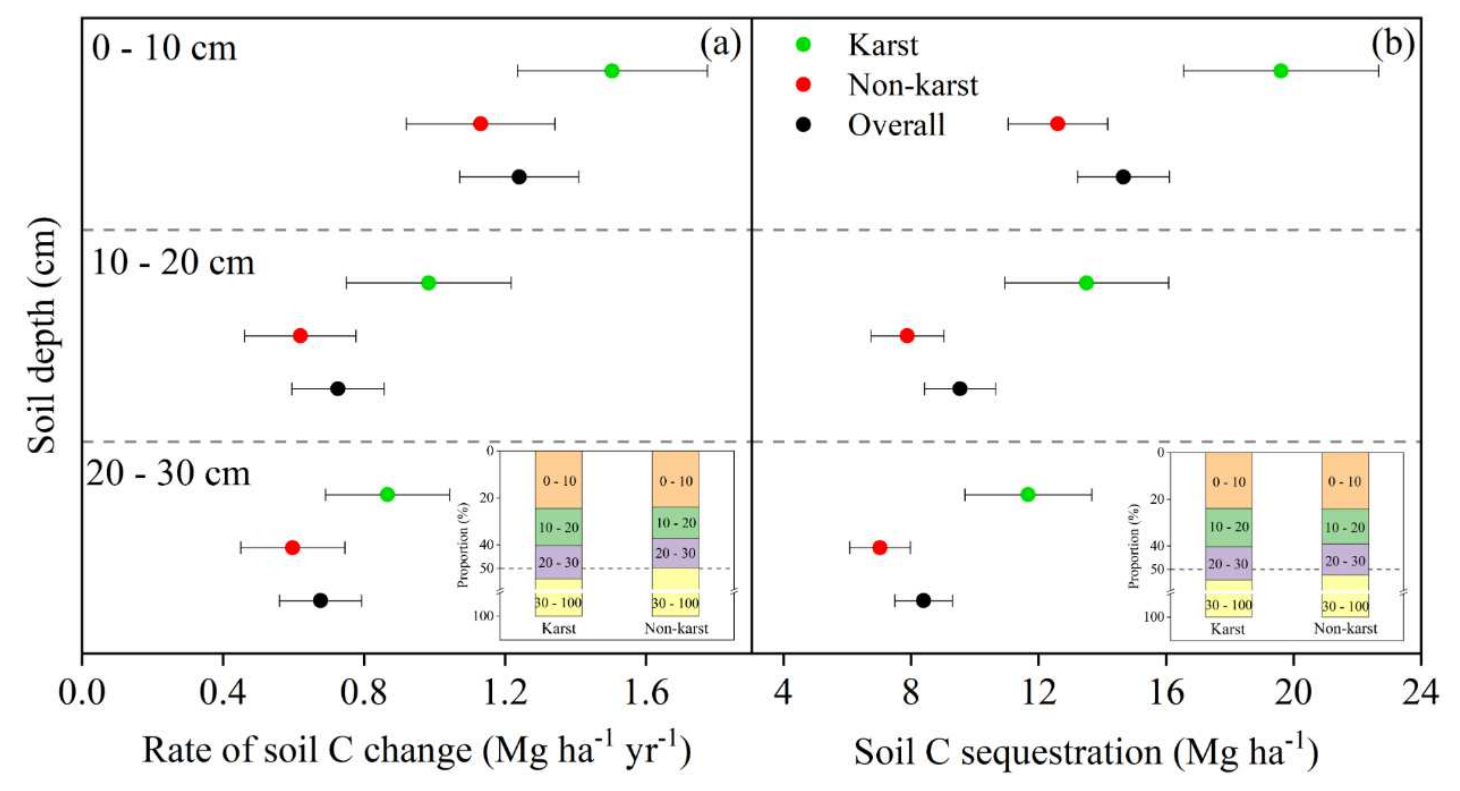


Fig. 3

635

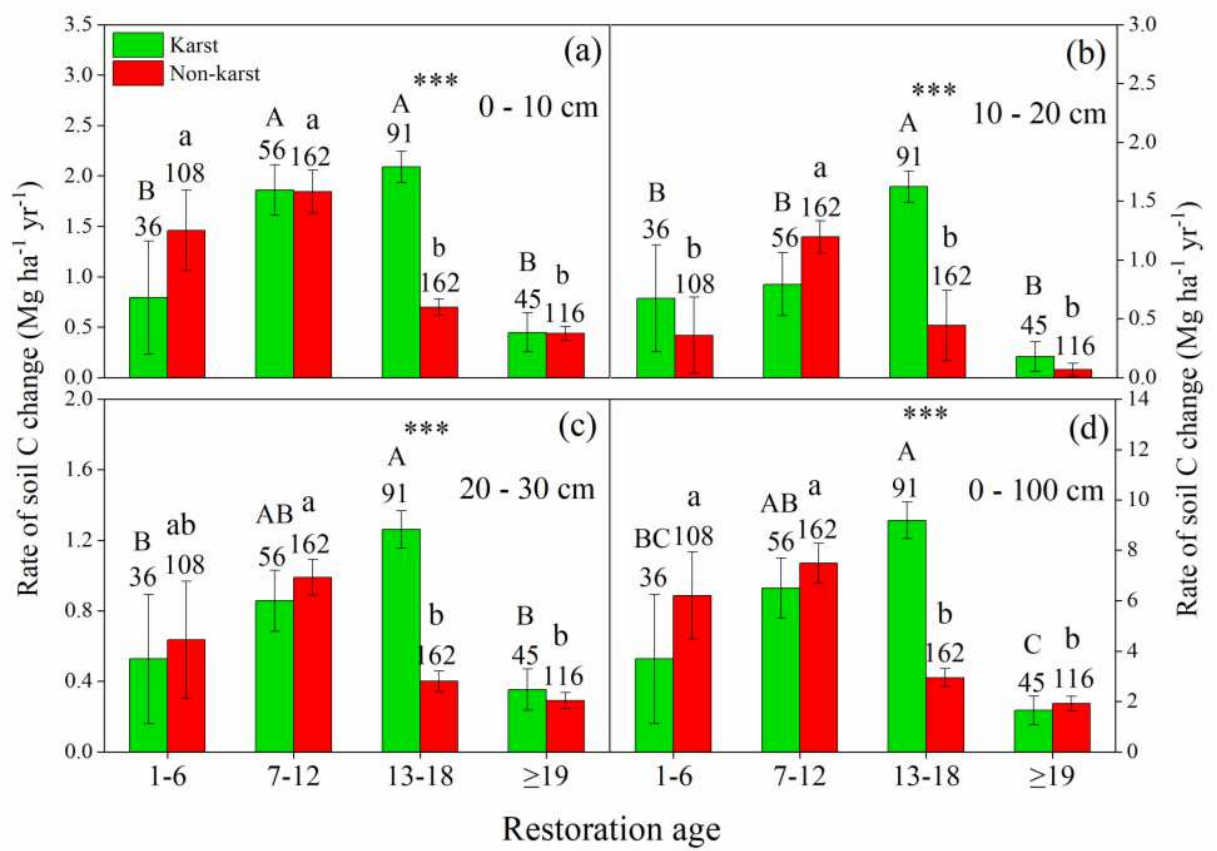

636 
Fig. 4

639

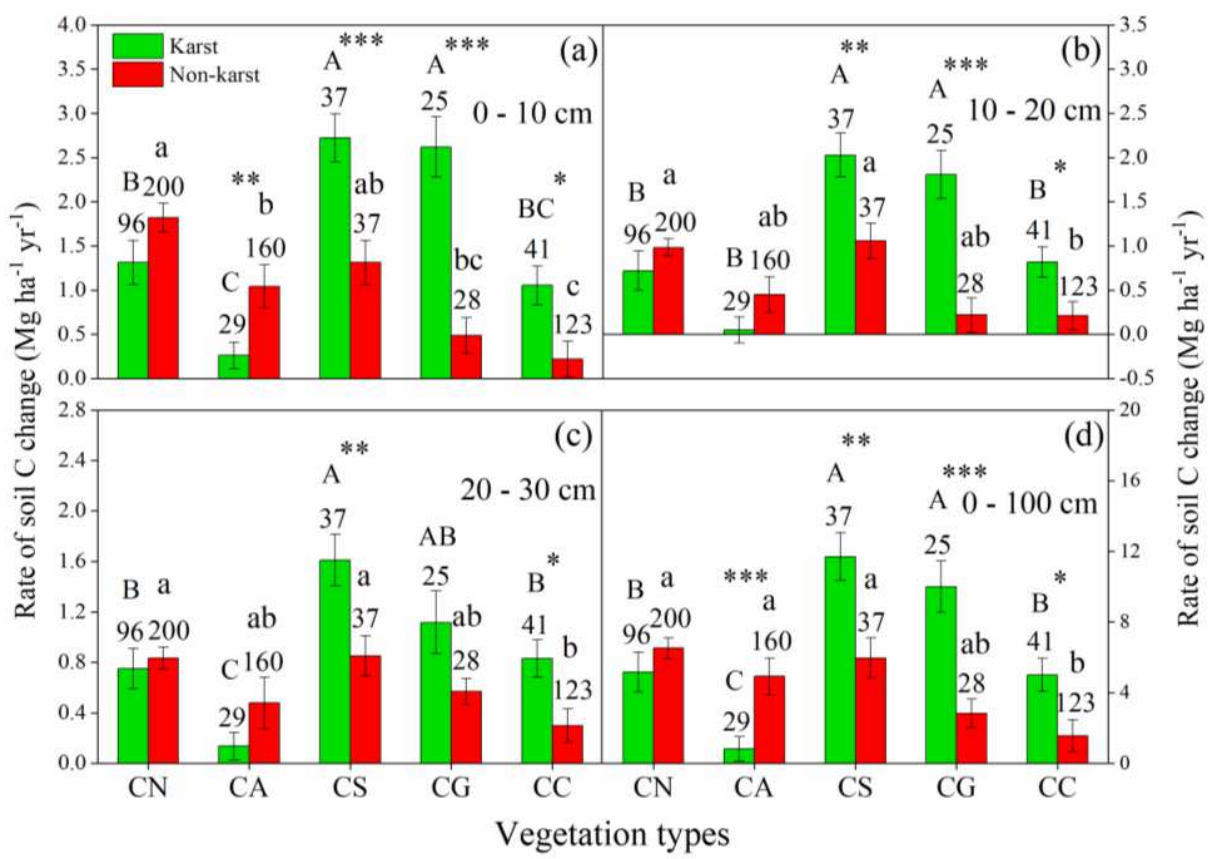

640

641 


\section{$643 \quad$ Fig. 5}

644
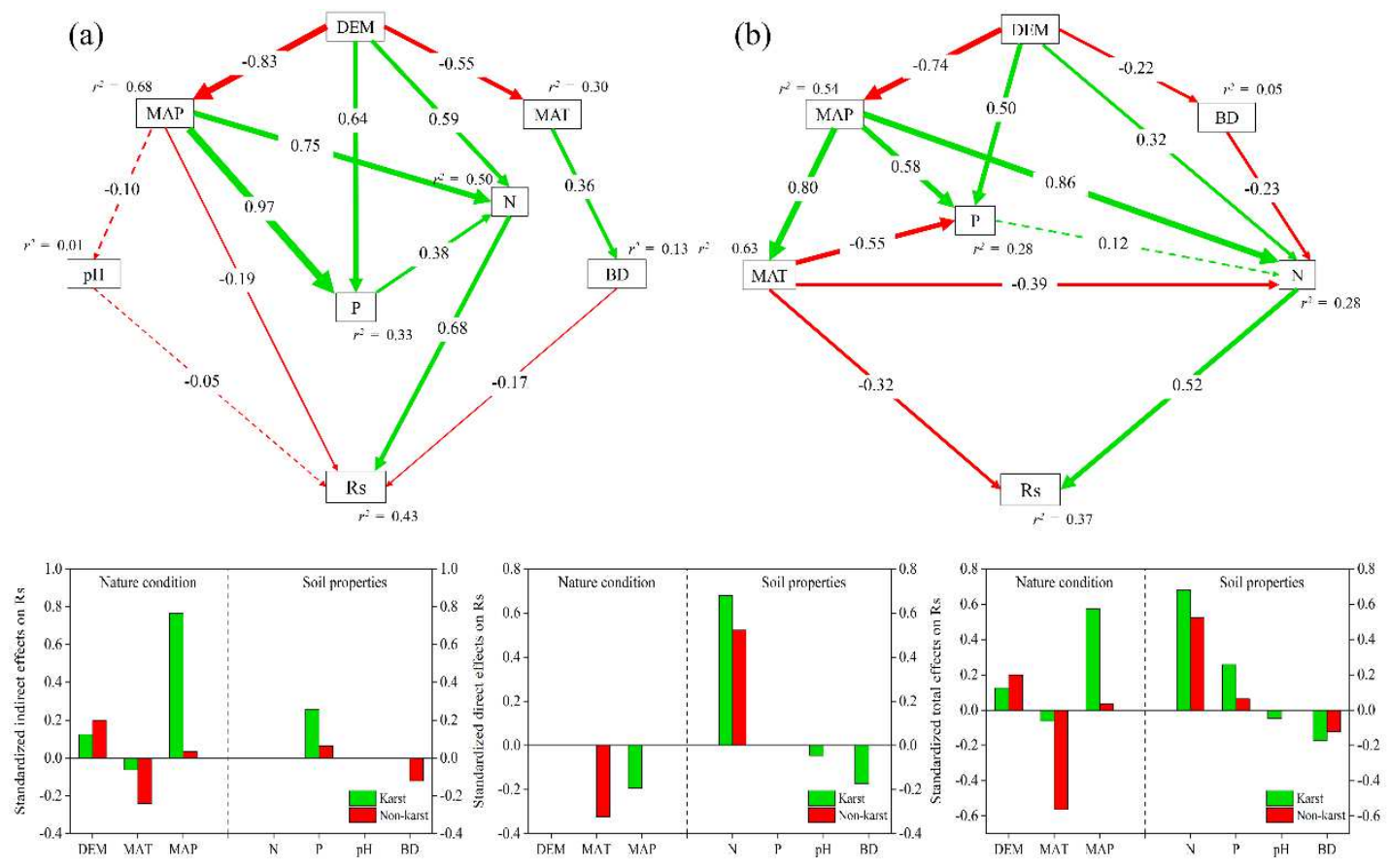

646

647

648 
650

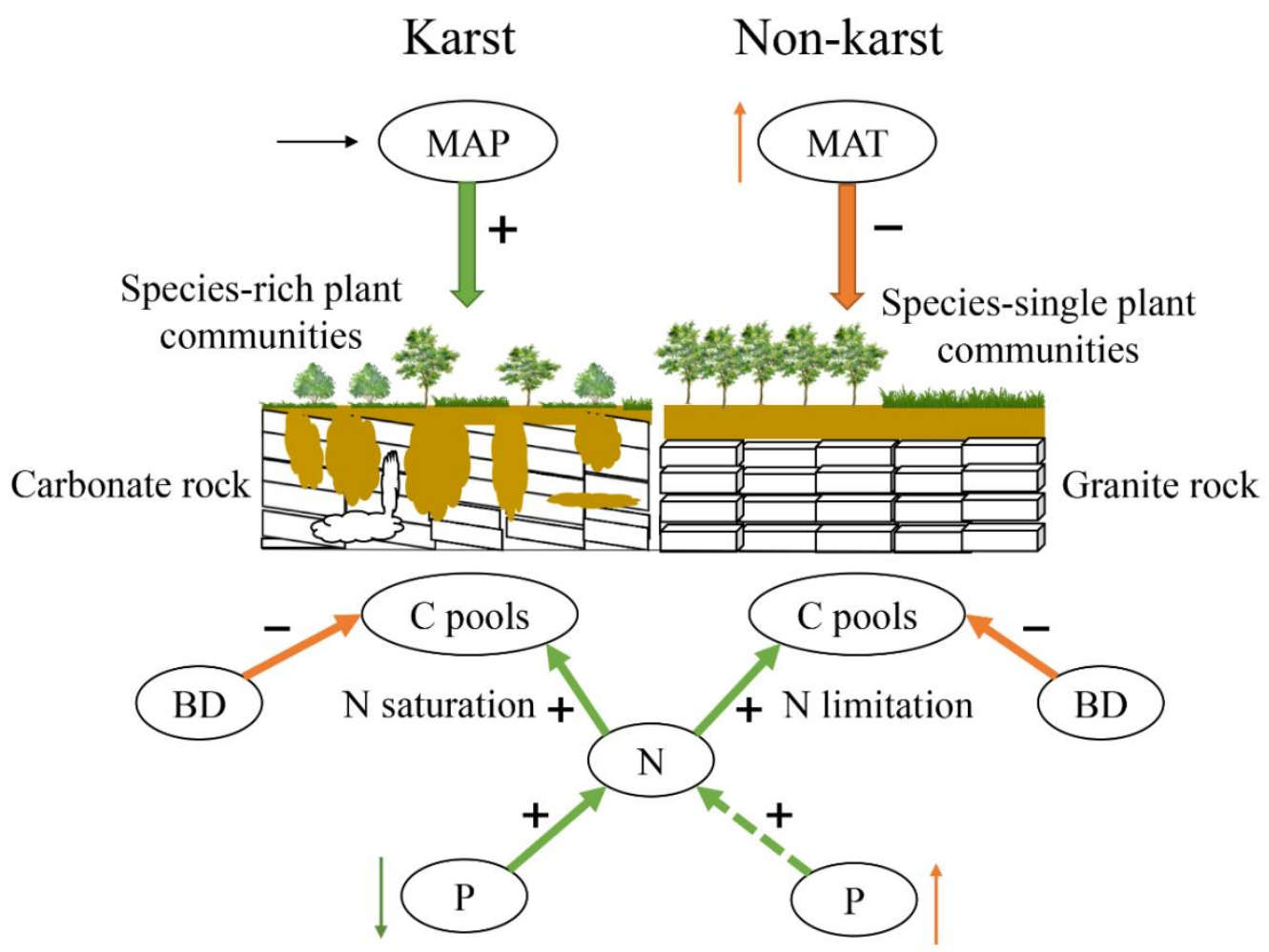


655 - All authors declare no conflict of interest.

656 


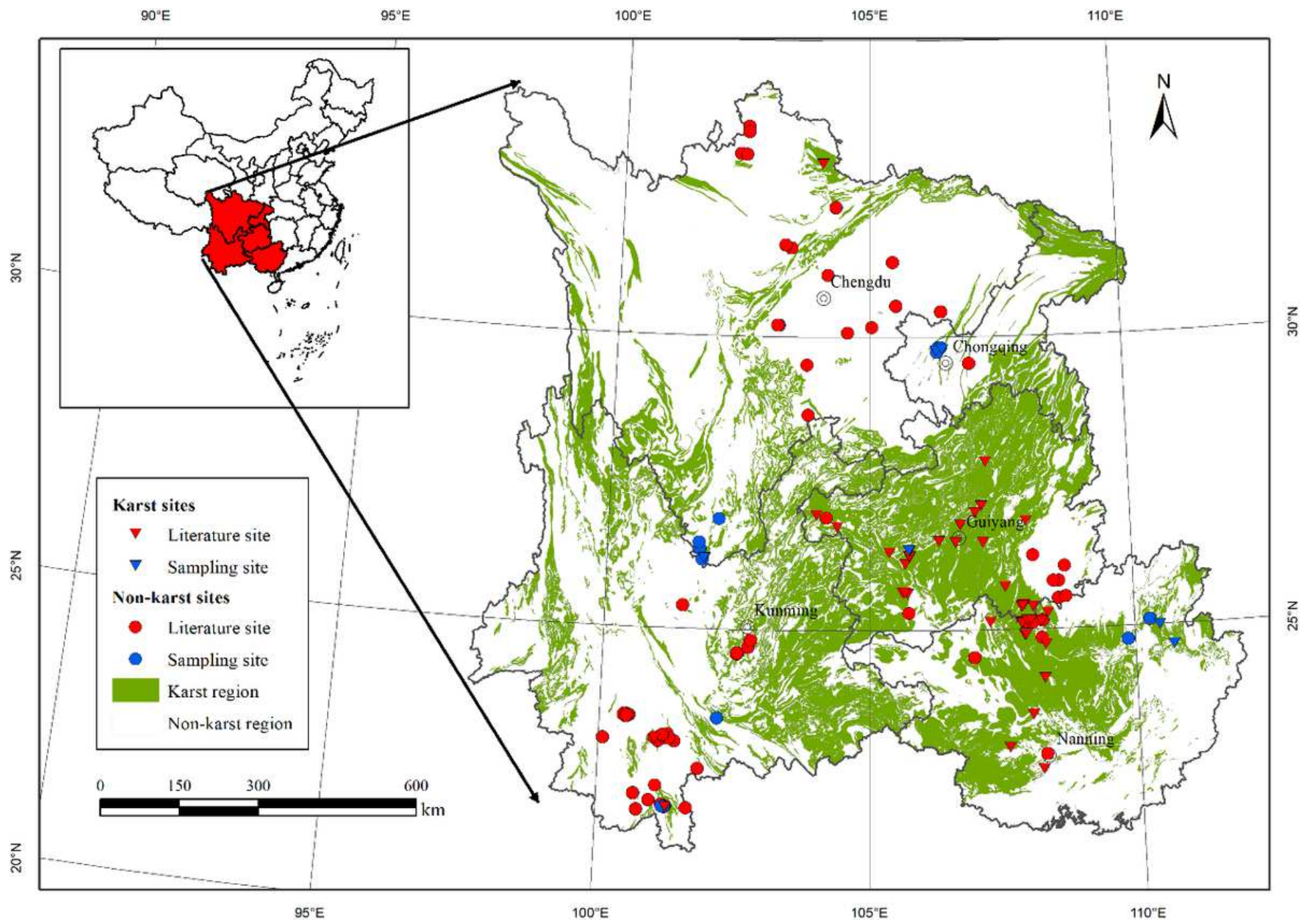

Figure 1

Spatial distribution of the observation sites in the dataset. All sites include multiple data entries. Note: The designations employed and the presentation of the material on this map do not imply the expression of any opinion whatsoever on the part of Research Square concerning the legal status of any country, territory, city or area or of its authorities, or concerning the delimitation of its frontiers or boundaries. This map has been provided by the authors. 


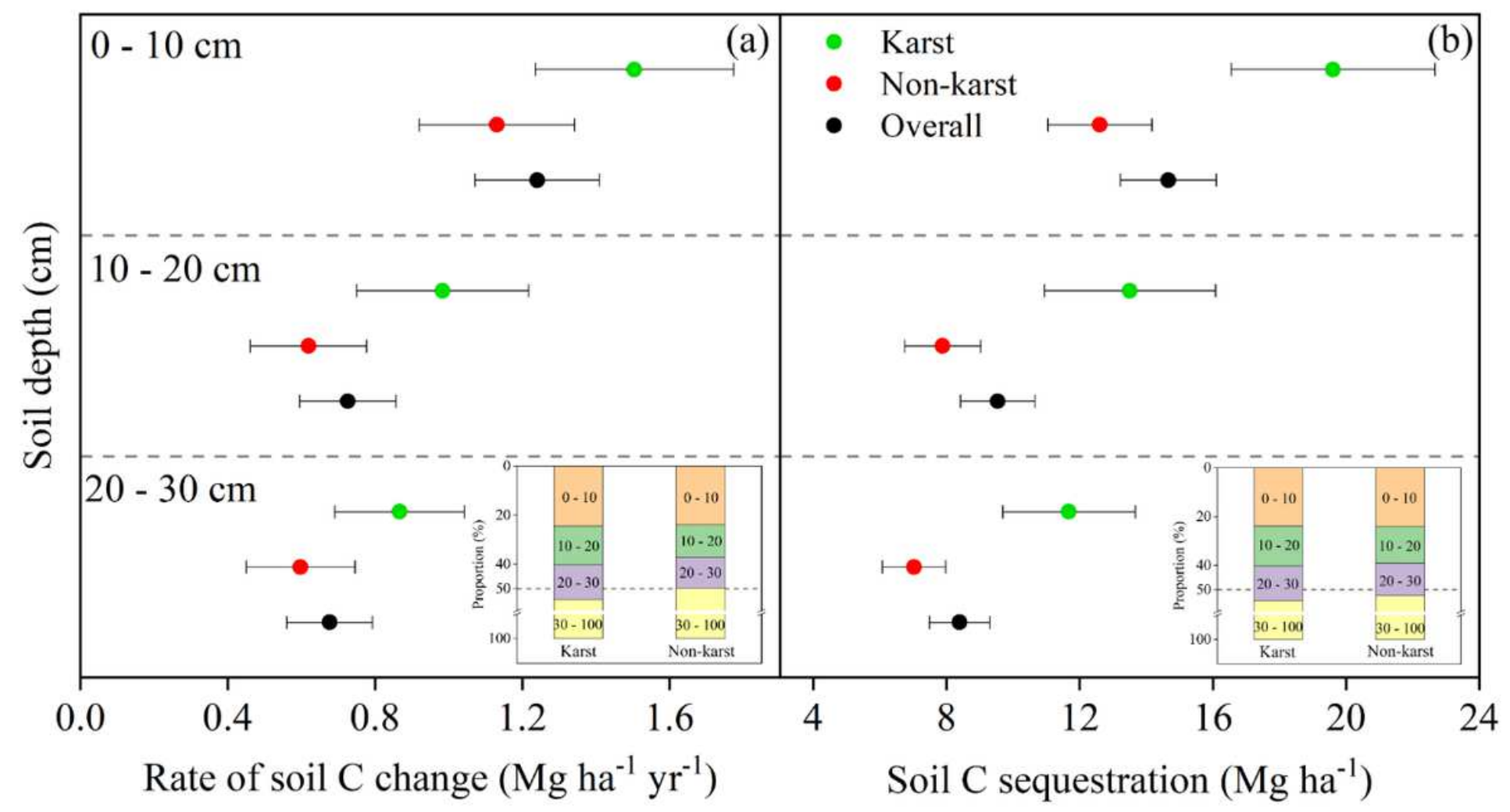

Figure 2

Changes in soil $\mathrm{C}$ stocks at different soil depths after vegetation restoration in karst and non-karst regions. (a) Rate and proportion of soil C change in the top $100 \mathrm{~cm}$ of the soil column. (b) Soil C sequestration and proportion in the top $100 \mathrm{~cm}$ of the soil column. Error bars represent $95 \%$ confidence intervals $(\mathrm{Cl})$. 


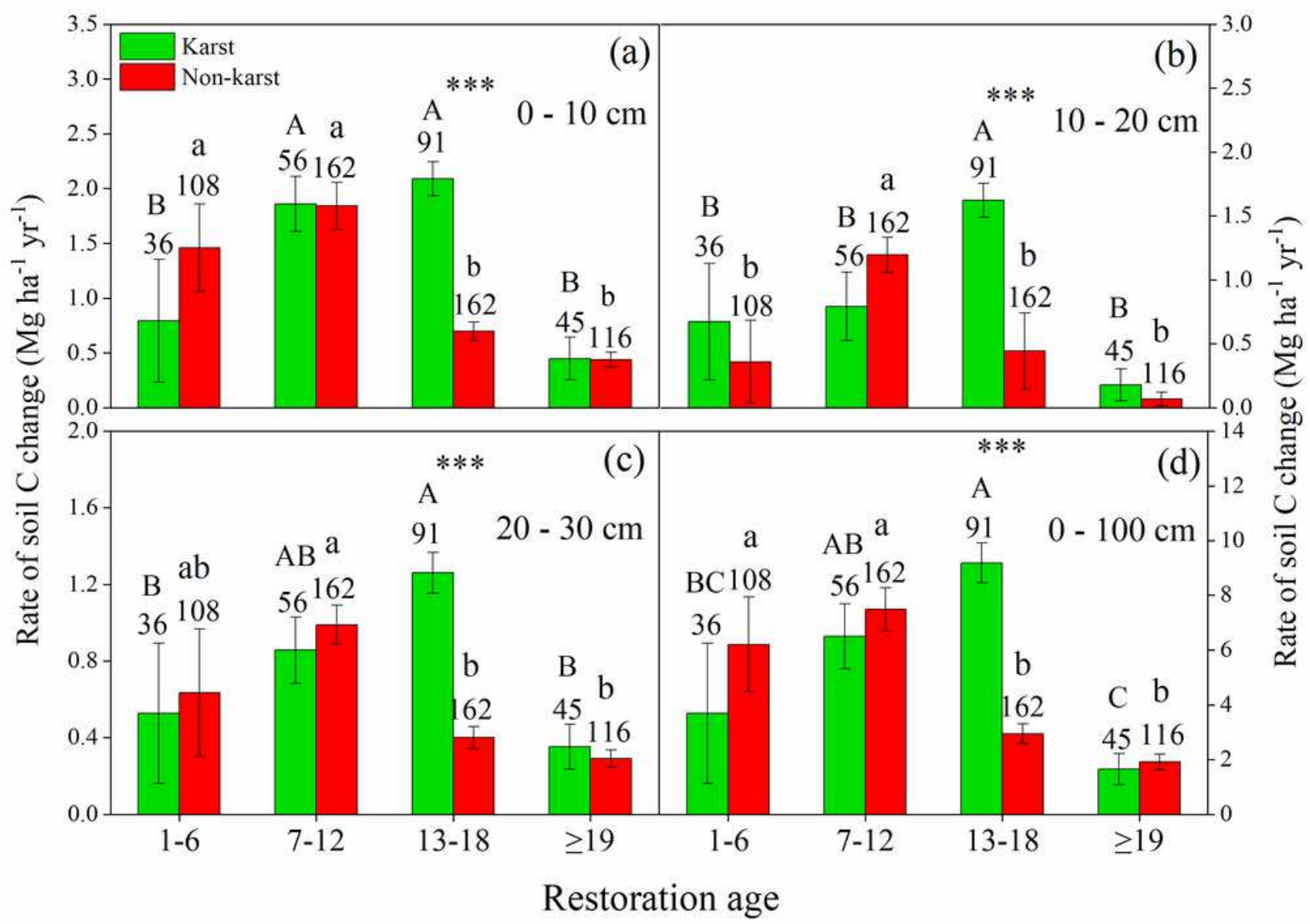

\section{Figure 3}

Variation in the rate of soil $\mathrm{C}$ change over time within different soil layers after vegetation restoration for: (a) soil at $0-10 \mathrm{~cm}$, (b) soil at $10-20 \mathrm{~cm}$, (c) soil at $20-30 \mathrm{~cm}$, and (d) soil at $0-100 \mathrm{~cm}$. The symbols *, $\star *$, and $* * *$ denote values where there are significant differences between the karst and non-karst regions, at $p<0.05, p<0.01$, and $p<0.001$, respectively. Different uppercase letters denote a significant difference among the different restoration stages of the karst at $p<0.05$. Different lowercase letters denote a significant difference between the different restoration stages in the non-karst regions at $p<0.05$. Values above the bars represent the number of observations. The error bars illustrate the standard errors (SE). 


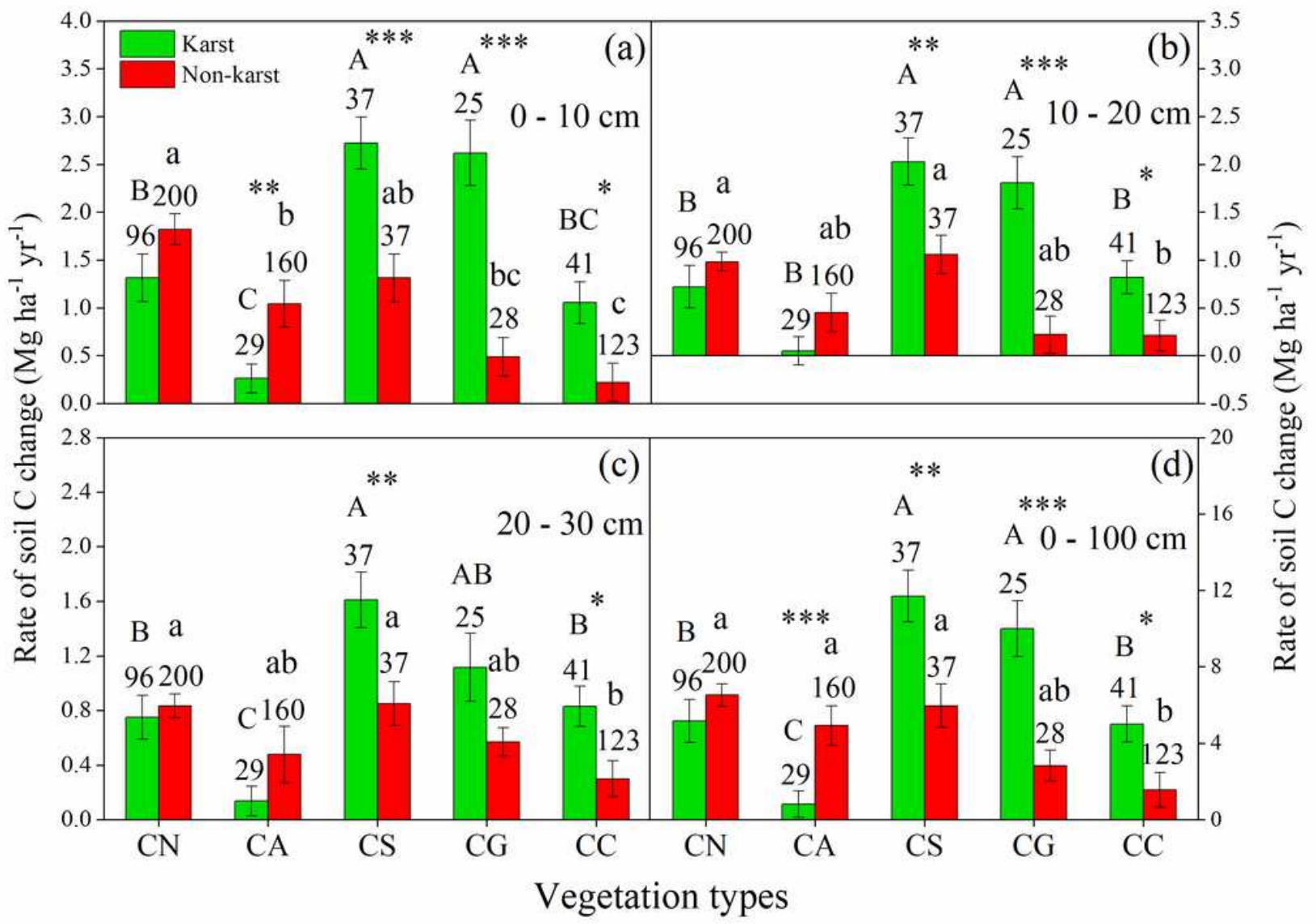

\section{Figure 4}

Variation in the rate of soil $\mathrm{C}$ change within different vegetation types at different depths after vegetation restoration for: (a) soil at $0-10 \mathrm{~cm}$, (b) soil at $10-20 \mathrm{~cm}$, (c) soil at $20-30 \mathrm{~cm}$, and (d) soil at $0-100 \mathrm{~cm}$. The symbols *, **, and $* * *$ denote values where significant differences occur between the karst and nonkarst regions, at $p<0.05, p<0.01$, and $p<0.001$, respectively. Different uppercase letters denote significant differences among the different restoration stages of karst at $p<0.05$. Different lowercase letters denote significant differences between the different restoration stages of non-karst at $p<0.05$. Values above the bars represent the number of observations. The error bars illustrate the standard errors (SE). 

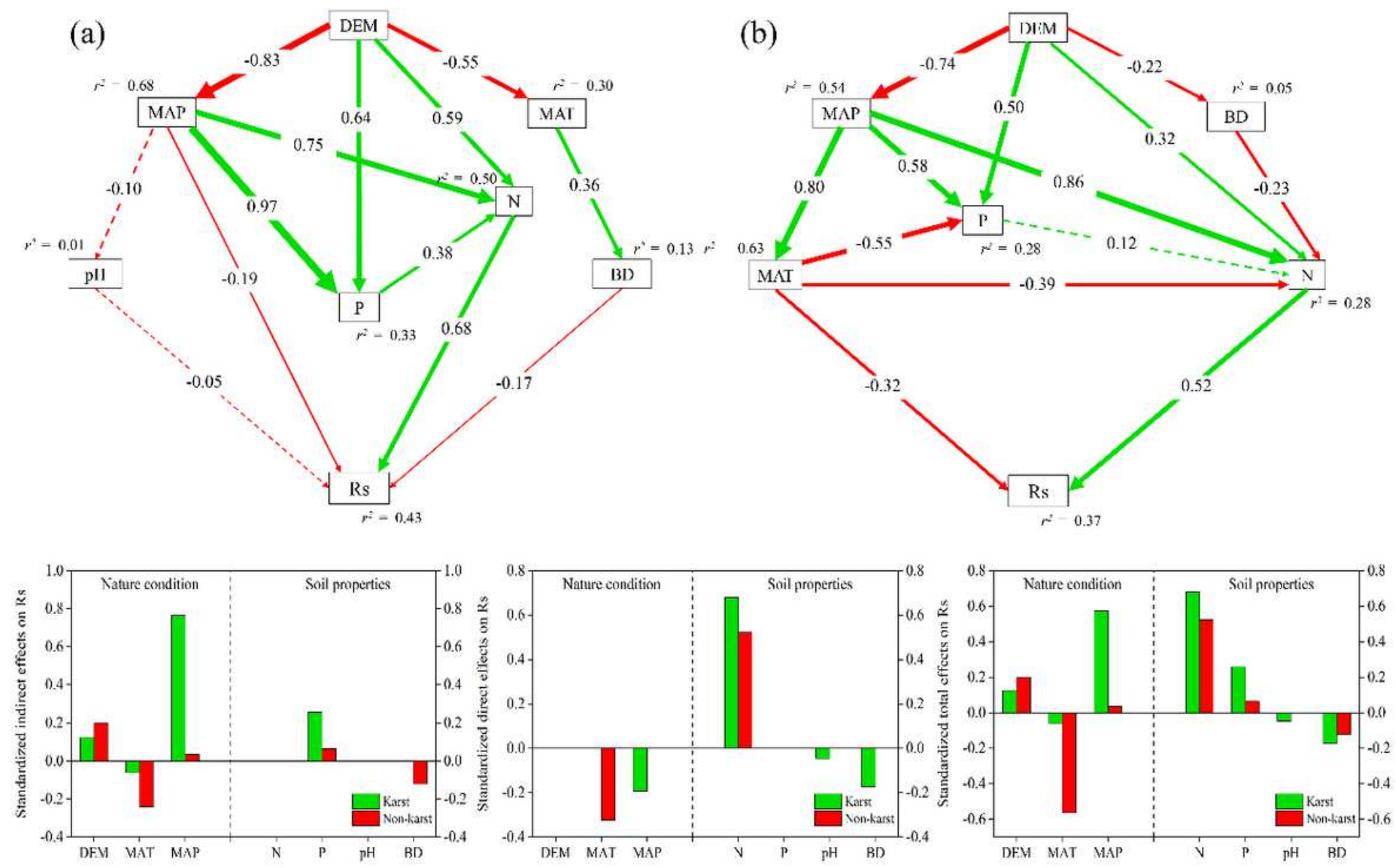

Figure 5

Final structural equation model for rate of soil $C$ change at depths from 0-100 cm. Green and red colors indicate positive and negative estimates, respectively. Green and red dashed lines indicate insignificant path coefficients $(p>0.05)$. Numbers on arrows are standardized path coefficients. The 2 values represents the proportion of variance in each endogenous variable. The width of the arrow indicates the strength of a path. (a) Model of karst $(n=76)$ with the factors affecting the rates of soil $C$ change $(\mathrm{CMIN} / \mathrm{DF}=0.754, \mathrm{GFI}=0.987, \mathrm{CFI}=1.000, \mathrm{NFI}=0.957, \mathrm{IFI}=1.015, \mathrm{p}=0.731$, and RMSEA < 0.001). (b) Model of non-karst $(n=100)$ with the factors affecting the rates of soil $\mathrm{C}$ change $(\mathrm{CMIN} / \mathrm{DF}=1.792, \mathrm{GFI}=$ $0.972, \mathrm{CFI}=0.978, \mathrm{NFI}=0.953, \mathrm{IFI}=0.979, \mathrm{p}=0.074$, and RMSEA $=0.089)$. The color histogram from left to right is indirect effect, direct effect and total effect. 


\section{Karst}

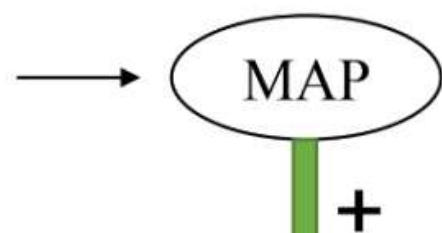

Species-rich plant

Carbonate rock communities

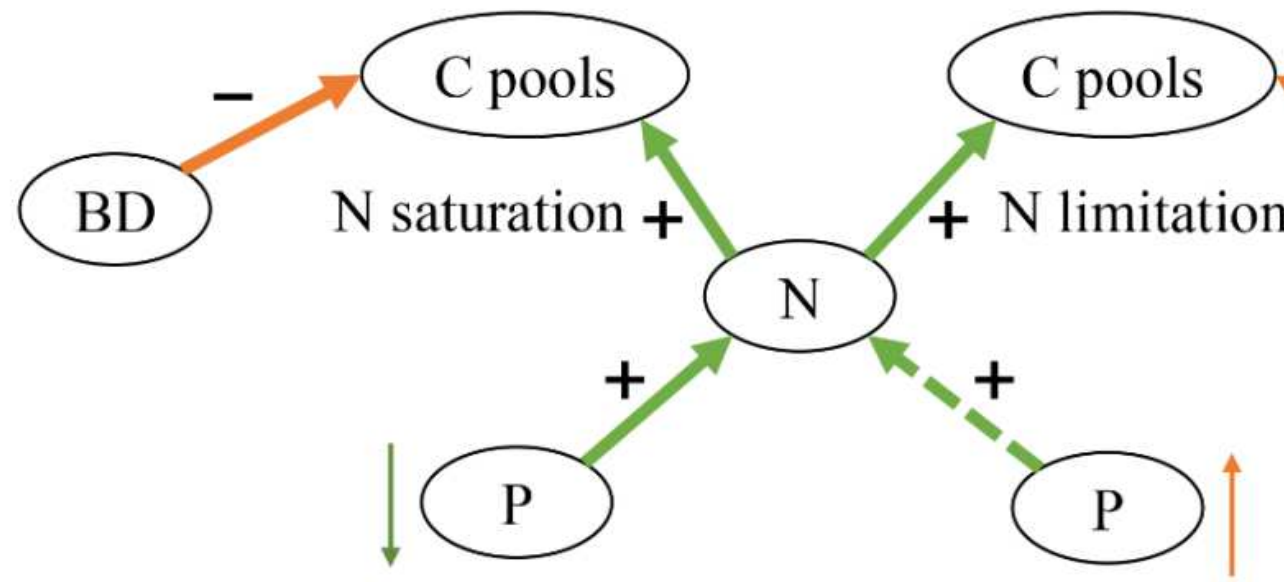

\section{Non-karst}

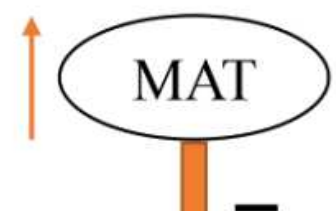

Species-single plant communities

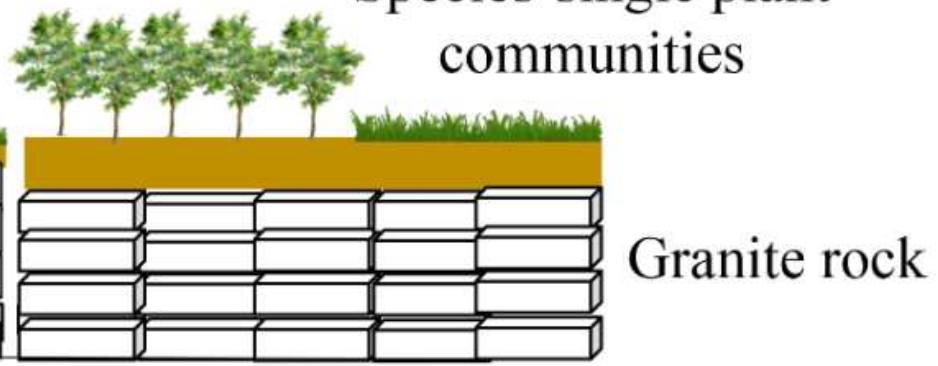

Figure 6

A conceptual diagram showing the differences mechanism in soil C sequestration processes between karst and non-karst areas. The diagram showing different lithology in karst and non-karst areas leading to different distribution of underground soil layers and aboveground vegetation community composition. BD has a negative effect on soil carbon pool growth throughout the study area. MAP and P in karst areas offset negative impacts on soil carbon pool growth due to $\mathrm{N}$ saturation. Growth of soil $\mathrm{C}$ pools in nonkarst areas limited by temperature rise and $\mathrm{N}$ increase. MAT: mean annual temperature; MAP: mean annual precipitation; BD: soil bulk density; N: soil nitrogen; P: soil phosphorus. The upward, downward, and horizontal arrows near the ellipse represent increase, decrease, and no change of the corresponding variables, respectively. The plus and minus signs next to the arrows between the variables indicate the positive and negative effects, respectively

\section{Supplementary Files}

This is a list of supplementary files associated with this preprint. Click to download. 
- SupplementaryMaterial.docx 